\title{
PEMIKIRAN KRITIS MULYADHI TERHADAP BANGUNAN ILMU MODERN
}

\author{
Andi Muhammad Ikbal Salam \\ Institut Agama Islam Negeri (IAIN) Parepare \\ Email: muhammad.ikbal1212@gmail.com
}

\begin{abstract}
Mulyadhi Kartanegara focused his attention on the discourse of Islamic philosophy whose ideas have been poured into various forms of scientific work. The epistemology of the integration of science Mulyadhi Kartanegara highlights aspects of the integration of the source of knowledge and the integration of science methods. The source of knowledge according to Mulyadhi is senses, reason and intuition, while Western scientists (materialism-positivism) only recognize the five senses as a source of knowledge. The science methodology in Mulyadhi's epistemology is the observation or experiment method for physical objects, the logical method for metaempiric objects, and the intuitive (irfani) method for recognizing objects directly. While modern scientists only recognize the science of observation or experimentation and dismiss other scientific methods. Furthermore, In the epistemological relations and ontological status, Islamic epistemology recognizes reality in an integrally-holistic manner (material nature, mitzal and reason and God is the peak of reality). Mulyadhi's critique of the building of modern science is addressed into empirical-rationalism (Cartesian-Newtonian paradigm) which provides the paradigm of thought: naturalism, idealism and secularism which is mechanistic in looking at the reality of the universe. Mulyadhi offered his critical response to materialism through epistemological Islamization on the aspect of science classification and science methodology.
\end{abstract}

Keywords: Mulyadhi, Thought, Modern Science

\begin{abstract}
Abstrak
Mulyadhi Kartanegara memusatkan perhatiannya pada diskursus filsafat Islam yang ide-idenya telah dituangkan ke dalam berbagai bentuk karya ilmiah. Epistemologi integarasi ilmu Mulyadhi Kartanegara menyorot aspek integrasi sumber ilmu dan integrasi metode ilmu. Sumber ilmu menurut Mulyadhi yakni indra, akal dan intuisi, sedangkan ilmuan Barat (materialisme-positivisme) hanya mengakui panca indra sebagai sumber ilmu. Metodologi ilmu dalam epistemologi Mulyadhi yakni, metode observasi atau eksperimen untuk obyek-obyek fisik, metode logis untuk obyek metaempirik, dan metode intuitif (irfani) untuk mengenal obyek secara langsung. Sedang ilmuan modern hanya mengakui metode ilmu observasi atau eksperimen dan menampik metode ilmu yang lain. Selanjutnya, dalam relasi epistemologis dan status ontologis, epistemologi Islam mengakui realitas secara integral-holistik (alam materi, mitzal dan akal dan Tuhan yang merupakn puncak realitas). Kritik Mulyadhi terhadap bangunan ilmu modern adalah tertuju pada rasionalisme-empirik (paradigma Cartesian-Newtonian) yang melahirkan aliran pemikiran: naturalisme, idealisme dan sekulerisme yang bercorak mekanistik dalam memandang realitas semesta. Selanjutnya Mulyadhi melontarkan respon kritisnya pada materialisme melalui islamisasi epistemologis pada aspek klasifikasi ilmu dan metodologi ilmu.
\end{abstract}

Kata kunci: Mulyadhi, Pemikiran, Ilmu Modern 


\section{A. Pendahuluan}

Kenyataan bahwa sains dan teknologi Barat Modern telah memiliki implikasi-implikasi negatif pada kehidupan manusia dan lingkungannya, salah satunya adalah hubungan agama dan sains yang tidak harmonis. ${ }^{1}$ Sehingga sebuah upaya dalam merespon tantangan sains modern penulis meminjam Istilah Isma'il Raji al-Faruqi, merupakan tanggung jawab bagi kaum akademikus Muslim.2 Sehingga penulis dalam studi ini berupaya dalam merespon sain yang telah jatuh kepangkuan ilmuan Barat yang telah melahirkan banyak problemproblem melalui penelusuran terhadap salah satu tokoh intelektual Muslim Indonesia yakni, Muyadhi Kartanegara.

Mulyadhi adalah sosok yang mungkin masih belum terlalu banyak yang tahu bahwa dia sebenarnya adalah sosok yang langka. Penulis meminjam asumsi Haidar Baqir yang memberi komentar terhadap Mulyadhi dalam buku menembus batas waktu, mengatakan bahwa Mulyadhi adalah sosok yang langka karena betapa cukup banyak orang belajar filsafat, tetapi lebih sedikit orang yang melirik filsafat Islam. Karena mungkin mereka beranggapan bahwa buat apa sih kita belajar filsafat Abad pertengahan. ${ }^{3}$ Secara umum juga dalam mempelajari filsafat ada yang berkomentar bahwa buat apa sih belajar filsafat, belajar filsafat memakan waktu banyak dan menguras energi intelektual, ${ }^{4}$ lebih sedikit lagi yang mau belajar disiplin kering nan "kuna" ini secara tekun dan akademis demikian jauh sehingga menghabiskan waktu studi sejak S-1 hingga mencapai gelar doktor.

Mulyadhi merupakan salah seorang diantara sekian banyak pemikir Muslim Indonesia. Melalui karyanya, ia menampilkan keluasan wawasan dan kecanggihan argumentasinya dalam menepis dan menunjukkan ketidak konsistenan para obyektifis Ilmuan Barat, yang sangat diagung-agungkan dalam menjawab tantangan kehidupan di era modern. Menelusuri kehiduapan entelektual Mulyadhi sesungguhnya merupakan sebuah penelusuran pengalaman eksperensial autobiografis. Tujuan penelitian ini adalah untuk mengungkapkan relasi epistemologi dan status ontologis integrasi ilmu Mulyadhi Kartanegara serta kritik pemikiran Mulyadhi Kartanegara terhadap bangunan keilmuan Modern?

\section{B. Pembahasan}

\section{Sosok Mulyadhi Kartanegara}

Beliau dilahirkan pada pada tanggal 11 bulan Juni Tahun 1959 di kampung dukuh kecematan Lego sebelah selatan kota Tanggerang Ayahnya

1 Armahedi Mahzar, Revolusi Integralisme Islam. (Cet. I: Mizan Bandung, 2004), h. 210-211.

2 Lihat Isma'il Raji al-Faruqi, Tanggung jawab Akademikus Muslim dan Islamisasi Ilmu-Ilmu Sosial, (Jakarta: Minaret, 1987), h. 28.

3 Mulyadhi Kartanegara, Menembus Batas Waktu: Panorama Filsafat Islam, ( Bandung: Mizan, 2002), h. xi-xii.

4 Donny Gahral Adian, Arus Pemikiran Kontemporer Atheisme: "Positivisme Logis, Neo Marxisme, Post Modernisme, Post Ideologi Syndrom", (Cet. I; Yogyakarta: Jalasutra, 2001), h. i. 
bernama R. H. Supriyadi dan Ibunya bernama Hj. Ety Suhaety, ${ }^{5}$ mereka tinggal dalam sebuah keluarga komunitas santri yang menganut aliran Ahl Sunnah wa al-Jama'ah dan merupakan anutan orang-orang di daerah tersebut sebagai sebuah aliran yang diyakini satu-satunya benar. Masa kecil Mulyadhi dilalui sebagaimana umumnya, tidak banyak yang istimewa yang dapat mendukung perkembangan intelektualnya. Setelah tamat dari SDN Legok tahun 1971 atas anjuran ibunya Mulyadhi melanjutkan pendidikannya di PGAN (Pendidikan Guru Agama Negeri) yang berarti dia harus pindah dari kampungnya. Namun dia sarankan untuk berhati-hati karena guru PGA adalah kebanyakan Muhammadiyah, sebuah istilah yang saat itu mengandung kesan negatif karena bertentangan aliran yang mereka anut. ${ }^{6}$ Selanjutnya Mulyadhi pindah Sekolah Persiapan (SP) IAIN (Institut Agama Islam Negeri) atas izin ayahnya. Selama dua tahun di SP IAIN Mulyadhi mengalami perkembangan yang cukup berarti berkat ketekunan membaca.

Pada tahun 1978, Mulyadhi melanjutkan studinya di IAIN Syarif Hidayatullah Jakarta pada Fakultas Ushuluddin. Tempat inilah yang membuat Mulyadhi merasa mulai mengalami perkembangan karir intelektual. Setelah menyelesaikan studinya di IAIN Syarif Hidayatullah Jakarta. Perkembangan tingkat intelektual yang begitu tinggi dirasakan Mulyadhi ini pulalah yang memberinya kesan, penghargaan akan tulisan-tulisan akademis konvensional seperti tesis tidak begitu tinggi jika dibandingkan di Indonesia. Pertimbanganpertimbangn ini yang membuat Mulyadhi memutuskan untuk menulis kembali tentang Rumi karena risetnya tidak dimulai dari awal lagi namun hanya pengembangan dari skripsi yang pernah ditulisnya. ${ }^{7}$

Kemudian pada Tahun 1996 Mulyadhi meraih gelar doktor filsafat dengan disertasi berbahasa Arab Mukhtasar Siwan al-Hikmah, berisi sekitar seribu kata mutiara dari 60 filosof Yunani dan 13 filosof Muslim. Karya Mulyadhi ini sesungguhnya tidak tergolong sepenuhnya pada bidang filsafat, tetapi tidak juga tergolong masuk dalam kategori sastra Arab (filologi) sepenuhnya, melainkan hasil editing dari manuskrip Umar Ibn Shahlan al-Sawi. Walaupun agak pragmatis karya Mulyadhi ini, tetapi lebih merupakan kompromi perfeksionisme dengan mengorbankan keterlibatan eksistensial seorang Mulyadhi yang menjadi idealisme filosofisnya.

Pragmatisme-intelektual tersebut terpaksa dijalani sebab pada awalnya Mulyadhi ingin menulis tentang Iqbal tetapi sayangnya tulisan tentang Iqbal di Universitas Chicago sudah terdapat kurang lebih seribu katalog. Kemudian ia mencoba memeras pikiran untuk mencari tema lain, dan menghasilkan tiga tema yaitu; teori atom Asy'ari, kritik Suhrawardi atas logika Aristotelian, dan jawaban

5 Mulyadhi Kartanegara, Mozaik khasanah Islam: Bunga Rampai dari Chicago, ( Jakarta: Paramadina, 2000), h. 205.

${ }^{6}$ Mulyadhi Kartanegara, Menyibak Tirai Kejahilan: Pengantar Epistemologi Islam, (Bandung: Mizan, 2003). h. xvi.

7 Mulyadhi Kartanegara, Seni Mengukir Kata: Kiat-Kiat Menulis Efektif-Kreatif, h. 231-234. 
Mulla Shadra terhadap kritik Kant. Namun keinginan itu terpaksa diurungkan dengan alasan wafatnya Prof. Fazlurrahman yang sangat potensial untuk menjadi pembimbingnya, di samping waktu yang tersedia untuk beasiswanya sudah sangat mendesak, ditambah lagi dengan kultur Universitas Chicago yang kurang memperhatikan karya-karya akademis.

Dari beberapa pertimbangan tersebut Mulyadhi kemudian mengurungkan niatnya dan menerima tawaran Prof. Wadad al-Qadhi untuk mengedit Mukhtasar Siwan al-Hikmah 8 karena menurut Prof. Al-Qadhi disertasi lebih seperti "SIM" bagi pengemudi mobil. Jadi disertasi bukanlah akhir tetapi justru awal karir seorang intelektual, sebagaimana SIM adalah awal karir seorang sopir. Awal karir seorang cendekiawan justru dimulai setelah meraih gelar doktor dengan menyelesaikan disertasinya. Dengan demikian dalam suasana tertentu pengorbanan seperti ini tentu diperlukan demi penyelamatan karir.

\section{Relasi Epistemologi dan Status Ontologis}

Berangkat dari pemetaan kontruksi epistemologis Barat dan Islam bahwa kedua konstruksi tersebut sesuai dengan kepercayaannya kepada dunia metaempirik, memiliki perbedaan yang fundamental. Lewat cerminan epistemologi Barat maka menghasilkan keraguan bahkan menampik status ontologis metaempirik, sementara konstruksi epistemologi Islam mencerminkan kepercayaan yang kuat terhadap status ontologis dari bukan hanya obyek-obyek empirikal, namun juga obyek-obyek metaempirik yang tak mampu diserap hanya melalui persepsi indrawi. ${ }^{9}$

Dalam salah satu tulisannya, Mulyadhi menyodorkan perbandingan antara epistemologi barat yang terjebak hanya pada penggunaan indrawi, sehingga dalam menyorot persoalan ontologi hanya akan melihat dimensi empirikalnya, dikatakan bahwa jika ilmu dianalogikan "cahaya" dan "kejahilan" sebagai "kegelapan", maka cahaya yang dipancarkan ilmu-ilmu yang lahir dari rahim epistemologi Barat tak ubahnya seperti cahaya redup yang tak cukup terang menyinari sisi gelap kehidupan manusia modern. Sedangkan epistemologi Islam menyodorkan tiga alat epistemik yakni: indra, akal dan intuisi sehingga pada penelusuran ontologi tidak hanya akan menyinari realitas sebatas pada kenyataan empirik akan tetapi juga menangkap dimensi realitas metaempirik, sehingga berujung pada penentuan nilai yang integral, holistik dan absolut. 10

Obyek-obyek empirikal oleh ilmuan Muslim disebut sebagai mahsusat (obyek-obyek ditangkap oleh indra), dan obyek-obyek metaempirik meraka

${ }^{8}$ Mulyadhi Kartanegara, Seni Mengukir Kata: Kiat-Kiat Menulis Efektif-Kreatif, h. 237-243.

${ }^{9}$ Mulyadhi Kartanegara, Nalar Religius: Memahami Hakikat Tuhan, Alam dan Manusia, h. 67.

10 Zainal Abidin Baqir, Jarot Wahyudi dan Afnan Anshori, Integrasi Ilmu dan Agama: Interpretasi Untuk Aksi, h. 206. 
sebut sebagai $m a^{\prime}$ qulat (obyek-obyek yang tidak dapat ditangkap melalui panca indra, melainkan hanya dapat ditangkap oleh akal manusia).

Kepercayaan hanya pada dimensi empirikal status ontologis, tentu berimplikasi pada klasifikasi ilmu, demikian pula pada konstruksi keilmuan Islam, kepercayaanya kepada status ontologis bukan hanya pada dimensi empirikal, namun melampaui itu yang padanya dilekatkan nama metaempirikal tentu juga berimplikasi pada klasifikasi ilmu.

Meskipun dalam hal perincian klasifikasi ilmu memiliki variasi, tetapi para ilmuan atau filosof muslim pada umumnya sepakat untuk membagi ilmuilmu teoritis (Nazhariyat), dan ilmu-ilmu praktis (amaliyyat). Kemudian ilmu-ilmu teoritis dibagi lagi menjadi metafisika, matematika, dan ilmu-ilmu alam.11 Taqi Mishbah pun dalam bukunya menyinggung persoalan tersebut, berawal dari Socrates menyebut dirinya sebagai filosof, lalu istilah filsafat digunakan sebagai lawan dari sophistry (ke-sofis-an atau kerancuan berpikir), dan memuat seluruh ilmu hakiki (real science), seperti fisika, kimia, kedokteran, astronomi, matematika, dan teologi. Atas dasar asumsi tersebut sehingga filsafat dianggap sebagai kata umum untuk seluruh ilmu hakiki, yang dibagi menjadi dua kelompok umum: ilmu-ilmu teoritis dan praktis. Ilmu teoritis meliputi ilmu-ilmu alam, matematika, dan teologi. Ilmu-ilmu alam meliputi kosmogoni, mineralogi, botani, dan zoologi; matematika meliputi aritmatika, geometri, astronomi, dan musik. Teologi dipilah menjadi dua kelompok: metafisika atau perbincangan umum tentang wujud, dan teologi ketuhanan. Ilmu-ilmu praktis memiliki tiga cabang: etika, moralitas/ akhlak; ekonomi domestik, dan politik.12

Deskripsi di atas maka dapat dipahami bahwa dalam sudut pandang epistemologi Barat modern, melalui kontruksi sains empiriknya maka konsekuensi logisnya hanya mengakui status ontologis empirikal, yang dipertegas melalui pandangan positivistik Comte, yang dianggap ada itu hanyalah sesuatu yang dapat dijangkau melalaui observasi indrawi dan verifikasi empirik. ${ }^{13}$

Sementara itu epistemologi Islam tetap mempertahankan status ontologis tidak hanya obyek-obyek fisik, tetapi obyek-obyek matematika, dan metafisika, lebih dari itu ilmuan Islam telah menyusun hierarki wujud, dimulai dari entitasentitas metafisika, dengan Tuhan di puncaknya sebagai pemberi wujud bagi yang lain, ${ }^{14}$ kemudian menurun melalui alam "antara" (barzakh) yang bisa kita

11 Mulyadhi Kartanegara, Nalar Religius: Memahami Hakikat Tuhan, Alam dan Manusia, (Jakarta: Erlngga, 2007), h. 68. Lihat juga buku Mulyadhi Kartanegara, Mengislamkan Nalar: Sebuah Respons Terhadap amaodernitas, h. 6.

12 Muhammad Taqi Mishbah Yazdi, Buku Daras Filsafat Islam, h. 6.

13 Donny Gahral Adian, Arus Pemikiran Kontemporer Atheisme: "Positivisme Logis, Neo Marxisme, Post Modernisme, Post Ideologi Syndrom", h. 34.

14 Isma'il Raji al-Faruqi, Tauhid, diterjemahkan dari judul: Tawhid; Its Implications for Thought and life, (Bandung: Pustaka, 1988), h. 51. 
lihat percampuran antara unsur-unsur metaempirik, dengan bentuk yang unik menuju alam empirik, tempat kita hidup dan berkembang. ${ }^{15}$

Pertama yang digambarkan oleh al-Farabi adalah Tuhan yang berada di puncak hierarki wujud, termasuk al-Kindi memandang bahwa Tuhan adalah sebab pertama sebagai sebab pertama maka merupakan sebab bagi keberadaan wujud yang lain, dalam konsep ke-Tuhanan Ibn Sina dia memandang Tuhan sebagai Wajib al-Wujud (Wujud Niscaya) yang dipersandingkan dengan status ontologis alam sebagai mumkin-al-wjud (wujud yang mungkin atau potensial). Alam sebagai wujud potensial keberadaannya sangat bergantung pada wujud niscaya, dalam arti wujud yang senantiasa aktual, tanpa adanya wujud yang senantiasa aktual, alam sebagai wujud yang mungkin (potensial) akan tetap berada dalam keadaan potensial. Ia memang tidak mustahil untuk mengada, akan tetapi ia bisa mengada hanya apabila ada wujud lain yang telah aktual yang dapat mengubah potensi alam itu menjadi aktualitas.

Hierarki wujud yang kedua yaitu malaikat, al-Farabi menggambarkan wujud immateril melalui perspektif filsafat, malaikat memiliki nama dan deskripsi yang berbeda-beda, terkadang disebut akal oleh al-Farabi dan Ibn Sina, dianggap cahaya oleh Suhrawardi, adapun status ontologis para malaikat sebagai hierarki wujud kedua setelah Tuhan, malaikat-malaikat ini dipandang oleh para filosof Muslim memperoleh status ontologis lebih tinggi dan nyata daripada alam materil, sebagai bagian wujud dalam hierarki wujud. Akal aktif, dalam filsafat emanasi al-Farabi dan Ibn Sina, merupakan agen penting dalam pembentukan (formasi) dunia di bawah bulan dan isinya. Ibn Sina menyebut agen tersebut sebagai shahib al-suwar, pemberi bentuk. ${ }^{16}$

Hierarki wujud yang ketiga dijelaskan oleh al-Farabi yaitu, benda-benda langit atau benda-benda angkasa (celestial), digambarkan bahwa berbeda dengan para malaikat yang bersifat immateril, disatu pihak dan benda-benda fisik, yang terus bersifat materi, dipihak lain, benda-benda angkasa merupakan gabungan antara benda-benda immateril dan benda-benda fisik. Namun, justru karena benda-benda ini tidak murni fisik, karena memiliki jiwa menurut Ibn Sina, status ontologis benda-benda langit lebih tinggi dibanding status ontologis bendabenda murni fisik.

Hierarki wujud yang terakhir bagi al-Farabi adalah benda-benda bumi (terrestrial). Al-Farabi menjelaskan lima macam benda-benda bumi mulai dari yang terendah hingga yang tertinggi yakni, pertama: unsur-unsur, kedua: mineral, ketiga: tumbuh-tumbuhan, keempat: hewan non rasional, kelima: manusia. Benda-benda mineral dibagi menjadi dua bagian: batu-batuan dan logam-logaman, batu-batuan tentu memiliki hierarki mulai dari yang terendah seperti batu koral hingga batu yang mulia seperti zamrud dan berlian. Dikatakan oleh Ibn Sina bahwa batu-batuan mengalami gerak vertikal ketika

15 Mulyadhi Kartanegara, Menyibak Tirai Kejahilan: Pengantar Epistemologi Islam, 2003, h. 31. 16 Mulyadhi Kartanegara, Mengislamkan Nalar: Sebuah Respons Terhadap amaodernitas, h. 66. 
benda-benda mineral telah sampai pada puncak perkembangannya maka muncullah jenis makhluk hidup (organik) yang memiliki daya hidup atau (alnafs), daya yang dimiliki oleh tumbuhan adalah: tumbuh (growth), makan (nutritive), dan reproduksi (berkembang biak).

Kemudian selanjutnya benda bumi ialah hewan yang terbagi ke dalam non-rasioanal (binatang) dan rasional (manusia) yang tidak hanya tumbuh, makan, dan reproduksi, melainkan memiliki daya sensasi dan gerak. Sensasi adalah adalah daya pengindraan, dengan indranya hewan mampu melihat halhal di sekelilingnya, ia mampu mengetahui makanan-makanan atau minuman yang diperlukannya untuk menjaga kelangsungan hidupnya, kesadaran akan lingkungannya yang diperoleh oleh binatang hanya melalui indranya sehingga bersifat dangkal. Kesadaran yang dimiliki oleh binatang terhadap lingkungannya juga sifatnya sementara (temporal) bergantung pada masa kini dan terputus dari masa lalu dan masa mendatang, binatang tidak tahu barang sedikit pun tentang dunia dan sejarahnya. Daya yang kedua, adalah gerak, tentu daya ini merupakan hal yang penting bagi hewan untuk menjaga kelangsungan hidupnya seperti ayam, membutuhkan gerak untuk mencari makanan dan sebagainya.

Hewan yang kedua, adalah hewan rasional atau manusia, dibandingkan dengan hewan non-rasional tentu hewan rasional lebih tinggi hierarkinya, perbedaan mendasar antara hewan dan manusia adalah terletak pada ilmu dan imanya,17 manusia dengan ilmunya mampu melahirkan teknologi canggih dan melalui teknologi tersebut mampu menciptakan peradaban, dan yang tat kalah pentingnya adalah dengan ilmunya, manusia dapat menilai benar dan salah, dengan ini manusia mampu memiliki keimanan kepada Tuhan dan dengan keimanannya mampu taat, berserah diri dan mengikuti tuntunan kebenaran (ajaran ke-Tuhanan).

Melalui konstruksi gagasan yang berdasar pada bangunan filsafat Islam, status ontologis tidak hanya terbatas pada obyek-obyek empirikal sebagaimana apa yang telah disimpulkan oleh positivisme bahwa realitas yang ada hanyalah sejauh apa dapat dijangkau oleh panca indra melalui observasi dan verifikasi empirikal, namun juga pada obyek-obyek metaempirik, dan obyek-obyek ilmu juga berpadanan dengan hierarki wujud. Semakin tinggi posisi wujud dalam hierarki wujud, maka semaikin nyata dan fundamental status ontologisnya. Karena obyek-obyek metaempirik menduduki posisi yang lebih tinggi. ${ }^{18}$

\section{Kritik Pemikiran Mulyadhi Terhadap Bangunan Ilmu Modern}

Mulyadhi sebagai salah satu pemikir Islam Indonesia juga menyadari hal tersebut dan mengatakan bahwa memasuki millenium ketiga, ilmu pengetahuan modern masih akan menjadi faktor dominan dalam kehidupan manusia. Sebagai

17 Murtadha Muthahhari, Membumikan Kitab Suci: Manusia dan Agama, h. 72-75.

18 Mulyadhi Kartanegara, Menyibak Tirai Kejahilan: Pengantar Epistemologi Islam, h. 32-41. 
kekuatan raksasa, ilmu bisa saja secara potensial sangat destruktif atau konstruktif, tergantung pada bagaimana kita mengelolanya. Membiarkan ilmu dan aplikasinya dalam bentuk teknologi, berkembang begitu saja tanpa pengarahan yang sistematis bisa sangat berbahaya, mengingat kekuatannya yang sangat besar. Oleh karena itu segala upaya untuk menjinakkan dan menyesuaikan kekuatan raksasa ilmu dengan habitat kultur bangsa kita sehingga berdaya guna secara maksimal, perlu kiranya kita sambut dengan gembira sebagai bagian dari tanggung jawab moral setiap cendekiawan.19

Respon kritis Mulyadhi terhadap modernitas yang bernuansa positivistik dan materialistis yang membuat keterputusan terhadap dimensi Ilahiyah sehingga menjadi biang dari segala macam krisis kehidupan dan melahirkan sebagian manusia modern yang acapkali telah tercerabut dari akar-akar tradisi intelektual Islam. Bagi Mulyadhi tentu saja, kritik atau tantangan filosofis yang begitu serius dan berbahaya terhadap bangunan metaempirik, epistemologis, dan etis Islam, itu tidak boleh dibiarkan begitu saja tanpa respon dan bahkan kritik yang dapat dipertanggung jawabkan secara filosofis. Sehingga hal tersebut merupakan pekerjaan rumah yang begitu penting bagi setiap kaum akademik dalam bahasa al-Faruqi, karena kritik terhadap sebuah ide atau pendirian akan dianggap benar selama tidak ada yang membantahnya. ${ }^{20}$

Setelah menelusuri secara seksama perkembangan ilmu modern, akhirnya pada kesimpulan bahwa pada kenyataannya pandangan keilmuan modern telah menimbulkan persoalan-persoalan serius. Pembatasan lingkup ilmu oleh ilmuan-ilmuan Barat modern hanya pada obyek empirik, pada awalnya mungkin hanya berupa pembagian kapling antara akal dan agama. Namun, lambat laun pembatasan tersebut ternyata telah menjadi pembatasan atau defenisi realitas itu sendiri. Pembatasan lingkup ilmu tersebut ternyata telah mendorong banyak ilmuan Barat memandang dunia empirikal sebagai satusatunya realitas yang ada, seperti tergambar dari paham materialisme dan positivisme, yakni pandangan-pandangan filosofis yang berakhir dengan penolakan terhadap realitas metaempirik.

Implikasi yang dilahirkan dari kecenderungan pembatasan lingkup ilmu hanya pada obyek-obyek fisikal melahirkan paradigma21 positivistik yang reduksionis dan sekuler, dan pandangan ini tidak terjadi begitu saja melainkan diupayakan secara sadar dan sistematis sebagaimana yang dikutip oleh Mulyadhi dari asumsi Holmes Rolston III, sekularisasi ini dilakukan dengan, "menolak secara programatik kategori-kategori (sebab-sebab) formal, dan final, dalam setiap penjelasan ilmiah meraka." Seperti kita ketahui secara seksama

${ }^{19}$ Mulyadhi Kartanegara, Mengislamkan Nalar: Sebuah Respon Terhadap Modernitas, h. 1.

${ }^{20}$ Mulyadhi Kartanegara, Mengislamkan Nalar "Sebuah Respon Terhadap Modernitas", h. 27.

21 Paradigma, oleh Thomas Kuhn diberikan pengertian penggunaan dalam banyak arti diantarnya adalah model atau pola berpikir dan pandangan dunia kaum ilmuan. Penulis kutip dari kutipan Husain Herianto dalam bukunya Paradigma Holistik: Dialog Filsafat, Sains, dan kehidupan menurut Shadra dan Whitehead. (Jakarta: Teraju, 2003). 28. 
bahwa pada abad pertengahan, berkat pengaruh Aristoles, penjelasan ilmiah memerlukan empat kategori sebab: efisien, formal, material, dan final. Ilmu pengetahuan menurut Rolston, telah berhenti untuk melakukan pencarian makna-makna dalam pencarian mereka, karena menurut mereka pencarian makna seperti itu lebih pantas masuk kedalam wilayah agama daripada wilayah pengetahuan.

Positivisme dalam sorotan sejarah dan filosofis tumbuh subur pada abad ke 19 ketika empirisme mendominasi. Positivisme lahir dan berkembang di bawah naungan empirisme. Karenanya positivisme menyerang filsafat yang subyek kajiannya metaempirik, positivisme menyerang konstruksi pemikiran metafisika dengan tidak hanya menggunakan tuduhan-tuduhan seperti lazimnya dilontarkan oleh pendukung-pendukung doktrin empirikal. Ia tidak hanya mengatakan bahwa proposis-proposisi22 filosofis itu tidak bermanfaat bagi kehidupan praktis dan tidak dapat dibuktikan dengan metode ilmiyah, kaum positivis mengatakan bahwa proposi-proposisi itu bukanlah proposisi dalam arti logis, karena hal tersebut tidak mengandung makna. Akan tetapi proposisi tersebut omong kosong dan tak berarti apa-apa. ${ }^{23}$

Armahedi Mahzar juga mensinyalir tentang materialisme saintifik (positivisme), pada dasarnya tidak khusus sekedar meruntuhkan agama atau dimensi spiritual belaka, akan tetapi seluruh dimensi interior. Citra, simbol, konsep dianggap tak punya realitas esensial pada dirinya sendiri, melainkan sekedar representasi alam material yang nyata. Pikiran, kesadaran, jiwa, adalah properties (sifat-sifat) dari alam indrawi dan dinamika saraf. ${ }^{24}$

Rasionalisme-materialisme sebagai nafas Barat modern telah mengantarkan manusia modern menuju pada paradigma parsial terhadap realitas dan menggiring pada relativitas nilai. Dasar asumsi ini dapat dilihat pada tergesernya nilai-nilai religius dan realitas metafisik ke sudut kesadaran manusia modern, yang telah menimbulkan apa yang disebut oleh Sayyed Hossein Nasr sebagaimana yang dikutip oleh Mulyadhi sebagai krisis spiritual manusia modern.

Rasio atau akal telah dijadikan ukuran untuk mengetahui apakah sesuatu itu nyata ataukah hanya sebuah halusinasi. Sigmund Freud mengatakan bahwa, daripada menyembah Tuhan yang merupakan ciptaan pikiran manusia, lebih baik menghadapi dunia dengan gagah dan rasional. Sedangkan pengaruh

22 Proposisi biasa berupa ide partikular yang mengacu pada maujud tertentu seperti gunung bawa karaeng salah satu gunug yang berada di kab. Gowa, dan kadang-kadang berupa konsep universal yang bisa diterapkan padah contoh yang tak terhingga. Penulis kutip pada buku Muhammad Taqi Mishbah Yazdi, Buku Daras Filsafat Islam, h. 136.

${ }^{23}$ Muhammad Baqir al-Shadr, Falsafatuna>, diterjemahkan dari judul: Dirasah Mawdhu'iyah fi Mu'tarak al-Shira' al-Fikriy al-Qaim baina Mukhtalaf al-Islamiyah wa al-Maddiyah al-Diyaliktikiyah (alMarksiyyah), h. 56.

${ }^{24}$ Fritjof Capra, The Tao Of Physics: Meyingkap Kesejajaran Fisika Modern dan Mistisisme Timur, diterjemahkan dari judul, The Tao Of Physics: An Exploration of the Parallels between Modern Physics and Easter Mysticism, diterjemhakan oleh Aufiya Ilhamal Hafizh, h. xxi . 
materialisme dapat dilihat dari pemihakan sains modern terhadap hal-hal yang positivistik. Sebuah disiplin ilmu baru dikatakan saintifik, bila obyek-obyeknya bersifat empiris yang karenanya bisa diukur dan diobservasi secara indrawi.

\section{Simpulan}

Mulyadhi adalah salah satu di antara banyak intelektual Muslim yang menyodorkan konsep Islamisasi sains. Mulyadhi dengan konsep Islamisasi epistemologis sebagai bentuk naturalisasi menyodorkan epistemologi yang bercorak integral, Mulyadhi kembali memadukan klasifikasi ilmu dan metode ilmu yang disebut sebagai bentuk naturaliasi, setelah ilmuan Barat memisahkan bahkan menampik akal dan hati sebagai sumber dan metode ilmu, Sehingga berimplikasi pada klasifikasi ilmu yang hanya membatasi dirinya hanya pada sains yang bercorak empiris dan menganggap ilmu selain hal tersebut sebagai ilmu palsu ( $p s e u d o$ sains). Ilmuan Barat yang membatasi hanya pada panca indra sebagai satu-satunya sumber ilmu maka melahirkan klasifikasi ilmu pada level ontologis hanya pada realitas sejauh yang dapat ditangkap melalui panca indra. Berbeda dengan apa yang ditawarkan oleh Mulyadhi melalui konsep Islamisasi epistemologisnya, dia menyodorkan bukan saja panca indra sebagai sumber ilmu, melainkan akal dan intuisi. Sehingga pada dimensi ontologisnya bangunan epistemologi Islam bukan hanya mengakui level empirikal, namun level metaempirik dan trans-metaempirik, sehingga implikasinya pada klasifikasi ilmu mengakui bukan hanya ilmu fisika, namun ada matematika, dan metafisika.

Adapun kritik Mulyadhi terhadap bangunan ilmu modern yang dibangun di atas fondasi rasionalisme-empiris adalah pandangannya yang parsial, mereduksi pandangan alam dengan berdalih bahwa setelah Tuhan menciptakan alam ini maka dia tidak lagi memiliki campur tangan terhadapnya. Pandangan tersebut disebut sebagai teori pembuatan jam (clock maker theory) yang lahir dari rahim paradigma Cartesian-Newtonian. Berawal dari paradigma Cartesian-Newtonian lalu melahirkan banyak paham seperti, deisme, naturalisme, materialisme, dan sekulerisme. Aliran pemikiran yang lahir akibat dari inspirasinya terhadap paradigma Cartesian-Newtonian inilah yang menjadi sasaran respon kritis Mulyadhi. Mulyadhi dalam menjawab sekaligus merupakan tepisan atas pandangan tersebut meminjam teori baik dari ilmuan Barat yang termasuk sebagai penemuan kontemporer, dia juga menggunakan pandangan ilmuan dan filosof Islam yang lebih komprehensif dalam menjawab tantangan tersebut.

\section{Referensi}

Armahedi Mahzar, Revolusi Integralisme Islam. Cet. I: Mizan Bandung, 2004 Donny Gahral Adian, Arus Pemikiran Kontemporer Atheisme: "Positivisme Logis, Neo Marxisme, Post Modernisme, Post Ideologi Syndrom", Yogyakarta: Jalasutra, 2001 
Husain Herianto, Paradigma Holistik: Dialog Filsafat, Sains, dan kehidupan menurut Shadra dan Whitehead. (Jakarta: Teraju, 2003

Isma'il Raji al-Faruqi, Tanggung jawab Akademikus Muslim dan Islamisasi Ilmu-Ilmu Sosial, Jakarta: Minaret, 1987

Isma'il Raji al-Faruqi, Tauhid, diterjemahkan dari judul: Tawhid; Its Implications for Thought and life, (Cet I; Bandung: Pustaka, 1988

Muhammad Taqi Mishbah Yazdi, Buku Daras Filsafat Islam, Mizan Bandung, 2003

Mulyadhi Kartanegara, Seni Mengukir Kata: Kiat-Kiat Menulis Efektif-Kreatif, Bandung: MLC, 2005.

Mulyadhi Kartanegara, Menembus Batas Waktu: Panorama Filsafat Islam, Bandung: Mizan, 2002

Mulyadhi Kartanegara, Mengislamkan Nalar: Sebuah Respons Terhadap amaodernitas, Erlangga, Jakarta, 2007

Mulyadhi Kartanegara, Menyibak Tirai Kejahilan: Pengantar Epistemologi Islam, Bandung: Mizan, 2003

Mulyadhi Kartanegara, Mozaik khasanah Islam: Bunga Rampai dari Chicago, Jakarta: Paramadina, 2000

Murtadha Muthahhari, Membumikan Kitab Suci: Manusia dan Agama, diterbitkan oleh: Free Islamic Literature, Inc. Housto, Texas. Penyunting Haidar Baqir, Bandung, Mizan 2007

Zainal Abidin Baqir, Jarot Wahyudi dan Afnan Anshori, Integrasi Ilmu dan Agama: Interpretasi Untuk Aksi, Bandung, Mizan 2005 